九州大学学術情報リポジトリ

Kyushu University Institutional Repository

\title{
Performance Evaluation of Microbial Fuel Cell with Food Waste Solution as a Potential Energy Storage Medium
}

\section{Masud, Nahian}

Department of Mechanical Engineering, Bangladesh University of Engineering \& Technology (BUET)

Al-Mustasin Abir Hossain

Department of Mechanical Engineering, School of Engineering and Computer Science (ENCS), Washington State University

Md Jawarul Moresalein

Department of Mechanical Engineering, Bangladesh University of Engineering \& Technology (BUET)

Ali, Mohammad

Department of Mechanical Engineering, Bangladesh University of Engineering \& Technology (BUET)

https://doi.org/10.5109/4738573

出版情報: Proceedings of International Exchange and Innovation Conference on Engineering \& Sciences (IEICES). 7, pp. 96-102, 2021-10-21. 九州大学大学院総合理工学府

バージョン:

権利関係: 


\title{
Performance Evaluation of Microbial Fuel Cell with Food Waste Solution as a Potential Energy Storage Medium
}

\author{
Nahian Masud ${ }^{1 *}$, Al-Mustasin Abir Hossain ${ }^{2}$, Md Jawarul Moresalein ${ }^{1}$ and Mohammad Ali ${ }^{1}$ \\ ${ }^{1}$ Department of Mechanical Engineering, Bangladesh University of Engineering \& Technology (BUET), Dhaka, \\ Bangladesh, \\ ${ }^{2}$ Department of Mechanical Engineering, School of Engineering and Computer Science (ENCS), Washington State \\ University, Vancouver, USA. \\ *Corresponding author email: nahiannew2@gmail.com
}

\begin{abstract}
Microbial fuel cell (MFC) is a new source of renewable energy where wastewater is used as fuel. Various microorganisms and organic and inorganic compounds are present in wastewater. Microorganisms with various reactions produce electricity using these organic compounds. Advanced study on MFCs can bring it to practical use and reduce the over dependence on fossil fuel. But expensive proton exchange membranes (PEM), electrode material and low power generation is a big barrier towards its development. Besides the share of solid food waste in municipal waste is increasing day by day. Food waste has high number of bio-degradable compounds which can be used as the fuel of MFC. In current study, three MFCs are made with food waste solution and three different combinations of easily available electrode materials such as Copper, Zinc and Graphite. The measured voltage had its peak values between 8 to 10 hours since the experiment started. With the help of various equations, a one-dimensional single particle half-cell model was generated which was used to simulate voltage graph with respect to time. The experimental value was compared with the simulation result for each cell. The validation of experimental result was used to predict the best possible combination of electrodes in microbial fuel cell with food waste solution. Detail of this research will provide useful information on the usage of various electrode materials and food waste to be used in MFC.
\end{abstract}

Keywords: MFC, Electrode, Food Waste, Experiment, Simulation.

\section{INTRODUCTION}

The increasing energy demand of the modern era requires to open up new scopes for exploring new sources of renewable energy. Microbial Fuel Cell is one of the outcomes of this. It is a process where energy is produced by anaerobic digestion. More research on $\mathrm{MFC}$ is opening up new pathways to generate energy from this sustainable source. Energy generation from wastewater through MFC can help contributing to energy demands. Food Waste is generated from house, restaurants, canteen etc. on a daily basis. Most of the food wastes (FW) is dumped with municipal waste in the landfills. But fermentation of this food waste can be very useful as MFC solution. In a MFC bacteria uses organic compounds to generate electricity. Food Waste contain a lot of glucose, lactose, starch, cellulose and other organic polymers. After fermentation some of these compounds possesses to ethanol or other organic compounds. Bacteria easily can use all of these for respiration, through which electricity can be generated. It is known that FW has high energy potential and biodegradability [1].

MFC is an efficient electrochemical process which with the help of food waste can produce clean energy for the mankind. If the FW is kept into water for hydrolysis, with the help of bacteria it decomposes the organic compound in it. Microorganisms can oxidize these substrates to produce electron and protons. But oxygen is also required for this process. As this solution is kept in airtight container, microorganisms release electrons to anode. Through an external circuit, connected between anode and cathode, electrons flow to cathode. The cathode compartments have plenty of oxygen as it is exposed to air. Thus, electrons are released to electron acceptor, i.e., oxygen [2,3]. Dual chamber MFC can reduce the overall cost as no proton exchange membrane (PEM) is required here. With the help of easily available electrode materials, it is simpler to find the best suited electrodes to be used for microbial fuel cell.

MFCs can produce clean energy through catalytic activity of microbes as it is a bio-electrochemical system [3]. Microorganisms can help replacing the expensive catalysts used in traditional fuel cells [4]. Many factors can influence the performance of MFCs. Such as Supply and Consumption of Oxygen in cathode chamber, Oxidation of organic and inorganic compounds in anode chamber, transferability of electrons from anode chamber to anode etc. [5]. The higher the Biochemical Oxygen Demand (BOD) of the wastewater, the higher voltage it can generate. Because of high cost of Proton exchange membrane (PEM) the focus from single chamber MFCs has been shifted to dual chamber microbial fuel cell $[6,7]$. Higher voltage reading is obtained from dual chamber microbial fuel cell. The cathodic reaction can be a significant factor to impede the performance of microbial fuel cell [8].

In this work, a MFC was made with common materials such as graphite, copper and zinc. Three different cells are made with different combinations of electrodes. Its voltage and current reading are observed for 10 hours. The maximum voltage reading was more than $800 \mathrm{mV}$ which was obtained after 8-10 hours since the experiment was started. Then a mathematical model was developed with the help of mass balance equation, Butler-Volmer equation to validate the experimental results with simulation results. Finally, a conclusion was provided on the best electrode combination of microbial fuel cell. 


\section{EXPERIMENT}

\subsection{SOLUTION MAKING}

Household food waste was used to make the solution. Banana Split, peels of mango and other fruits, residue of vegetables, stale food and left-over foods of house was put into a container. Then water was poured into it. The ratio of food waste to water was 1:4. The solution was kept into the closed container for 7 days for the growth of bacteria. Also, the solution was mixed nicely with a stick and extra waste was added after every two days since the day it was first made. Finally, the product was filtered to separate the solids and it was ready to use. As there is a lot of organic compounds in the food wastes, they mix into the water which is perfect for the solution of microbial fuel cell.

\section{EXPERIMENTAL SETUP}

To conduct the experiment, two plastic containers were used as anode and cathode compartments. The capacity of both containers were 5 liters. In one of the containers the previously made solution of food waste was kept. Then an electrode, connected with external wire was kept in it. After that one side of a U-tube was immersed in the anode compartment as salt bridge. Agar agar powder and $\mathrm{KCl}$ (Potassium Chloride) solution was

\subsection{WORKING PROCEDURE}

There are a lot of bacteria in the food waste solution. Also, food wastes contain a lot of organic compounds such as glucose, fructose, ethanol, starch, cellulose etc. Bacteria use these compounds for respiration with the help of electron acceptor i.e., Oxygen. In the anode compartment, the solution was kept air tight. So, bacteria cannot leave the electrons to oxygen as there was a lack of oxygen. For this reason, they release the electrons to the electrode that was dipped into the compartment. The electrons travel through external wire to the cathode. The cathode compartment was open to the air and there is a plenty of oxygen in air $[9,10]$. The electron was then released to oxygen. Thus, the circuit was completed. As there was a flow of electron, a current was produced. Also, there must me a voltage difference between the anode and cathode to flow the electrons [11]. For different organic compounds different types of reactions are occurred. The organic compounds are decomposed into carbon-di-oxide and water with the help of bacteria. The following reactions are happened:

Oxidation (Anode):

Glucose:

$\mathrm{C}_{6} \mathrm{H}_{12} \mathrm{O}_{6}+12 \mathrm{H}_{2} \mathrm{O}--->6 \mathrm{HCO}_{3}{ }^{-}+30 \mathrm{H}^{+}+24 \mathrm{e}^{-}$

\section{(a)}
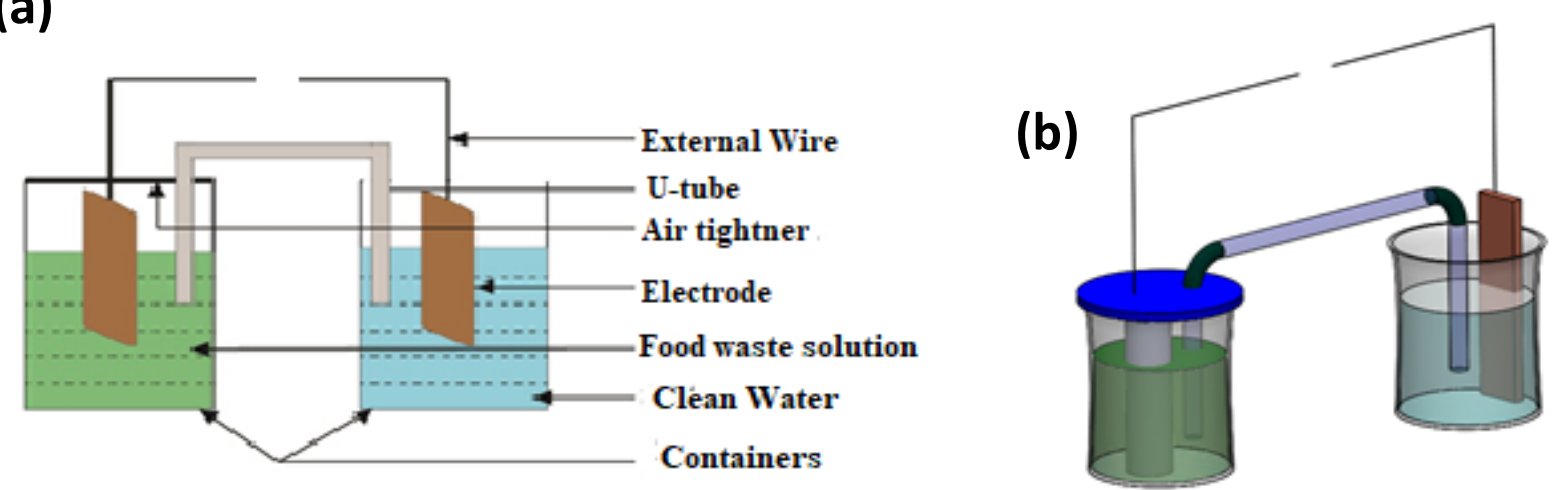

Fig-1: (a) 2D diagram of the experimental setup, (b) 3D diagram of Microbial Fuel Cell with Graphite and Copper electrode.

used in the U-tube. Finally, then compartment was sealed perfectly to resist microorganisms to respire with the help of oxygen in the air. The second plastic container was used as cathode compartment. Clean water was kept in it. The other side of U-tube and another electrode, connected with external wire was kept in it. This compartment was kept open for the air flow. As the experiment was done to read open circuit voltage (OCV), a multimeter was used to read the voltage and current reading. Figure 1 shows the experimental setup of MFC.

Three different MFC model was made with different electrodes. The anode-cathode combinations are CopperCopper, Zinc-Copper and Graphite-Copper. As graphite electrode is usually found in cylindrical form and zinc \& copper is found in plate from, electrodes were of different shape and size.
Ethanol:

$\mathrm{CH}_{3} \mathrm{COO}^{-}+4 \mathrm{H}_{2} \mathrm{O}---->2 \mathrm{HCO}_{3}^{-}+9 \mathrm{H}^{+}+8 \mathrm{e}^{-}$

$\underline{\text { Reduction (Cathode): }}$

Glucose:

$\mathrm{O}_{2}+4 \mathrm{H}^{+}+4 \mathrm{e}^{-}------>2 \mathrm{H}_{2} \mathrm{O}$

Ethanol:

$2 \mathrm{O}_{2}+8 \mathrm{H}^{+}+8 \mathrm{e}^{-}----->4 \mathrm{H}_{2} \mathrm{O}$

$\underline{\text { Overall Reactions }}$

Glucose:

$\mathrm{C}_{6} \mathrm{H}_{12} \mathrm{O}_{6}+6 \mathrm{O}_{2}----->6 \mathrm{CO}_{2}+6 \mathrm{H}_{2} \mathrm{O}$

Ethanol:

$\mathrm{CH}_{3} \mathrm{COO}^{-}+2 \mathrm{O}_{2}^{-}---->2 \mathrm{HCO}_{3}^{-}+\mathrm{H}^{+}$ 


\subsection{SPECIFICATIONS AND OUTPUTS}

The amount of food waste solution used for anode chambers in all three MFC was 4000 [ml]. Same amount of clean water was used in cathode camber too. A glass obtained from Copper-Copper combination.

\section{MODEL DEVELOPMENT}

Here, a mathematical model was developed to validate experimental results. The model was made as simple as

Table 1: Electrode Properties for various material

$\begin{array}{cccc}\text { Name } & \text { Shape type } & \text { Surface Area }\left(\mathbf{c m}^{\mathbf{2}}\right) & \text { Weight }(\mathbf{g r a m s}) \\ \text { Copper } & \text { Plate } & 123.18 & 30 \\ \text { Zinc } & \text { Plate } & 120.77 & 20 \\ \text { Graphite } & \text { Cylindrical bar } & 55.03 & 26\end{array}$

Table 2: Voltage and Current outputs of the Experiment

\begin{tabular}{|ccc|} 
Combination & Peak voltage $(\mathbf{m V})$ & Current $(\mathbf{m A})$ \\
\hline Copper-Copper & 900 & 0.1 \\
Zinc-Copper & 822 & 0.15 \\
Graphite-Copper & 585 & 0.1
\end{tabular}

Table 3: List of model parameters used in this study

\begin{tabular}{|c|c|c|c|}
\hline Parameters & Values & Units & References \\
\hline Columbic Capacity, Capa & Calculated from experiment & {$[\mathrm{mAh} / \mathrm{g}]$} & Measured \\
\hline Density of Graphite, $\rho$ & 2000 & {$\left[\mathrm{~kg} / \mathrm{m}^{3}\right]$} & {$[12]$} \\
\hline Exchange Current Density, $i_{0}$ & 0.0037 & {$\left[\mathrm{~A} / \mathrm{m}^{2}\right]$} & {$[12,13]$} \\
\hline Faraday Constant, $F$ & 96487 & {$[\mathrm{C} / \mathrm{mol}]$} & {$[12,13,14]$} \\
\hline Initial Concentration, $c_{01}$ & $x_{0} X c_{\max }$ & {$\left[\mathrm{mol} / \mathrm{m}^{3}\right]$} & Measured \\
\hline Initial Particle Radius, $r_{0}$ & $500 \times 10^{-9}$ & {$[\mathrm{~m}]$} & [12] \\
\hline Initial Solid Diffusivity, $D_{S}$ & $2 \times 10^{-15}$ & {$\left[\mathrm{~m}^{2} / \mathrm{s}\right]$} & {$[12]$} \\
\hline Initial State of Charge (SOC) of Graphite, $x_{0}$ & 0.0001 & & {$[13,14]$} \\
\hline Maximum Concentration, $c_{\max }$ & $\rho X \frac{\text { Capa }}{F}$ & {$\left[\mathrm{~mol} / \mathrm{m}^{3}\right]$} & Measured \\
\hline Surface to Volume Ratio, $a V$ & $3.91 \times 10^{6}$ & {$[1 / \mathrm{m}]$} & {$[12,16]$} \\
\hline Temperature, $T$ & 298 & {$[\mathrm{~K}]$} & {$[12,17]$} \\
\hline Time, $t$ & 10 & {$[\mathrm{~h}]$} & “ \\
\hline Thickness of Electrode, $L$ & $116 \times 10^{-6}$ & {$[\mathrm{~m}]$} & “ \\
\hline Universal Gas Constant, $R$ & 8.314 & {$[\mathrm{~J} / \mathrm{mol} / \mathrm{K}]$} & {$[12,17]$} \\
\hline
\end{tabular}

made U-tube was used. The multimeter model was DT9205A Digital Multimeter. The weight of the electrodes was measured on MEGA KING, Model: ASCA. The properties of electrode materials were stated in table 1 .

The peak voltage was found between 8-10 hours after the experiment had started. The current readings were almost the same throughout the experiment. The outputs were given in table 2 . The maximum voltage reading was possible. Therefore, the model development was started with a one-dimensional half-cell single particle model without any electrolytes. In this model, the graphite to be single phase, rather than a two-phase system $[12,13,14]$. The governing equations and boundary conditions (Table-3) for this model is discussed in the literature. These equations include mass balance equation, ButlerVolmer equation to describe electrochemical reaction at 
the interface. To estimate diffusion coefficients in particle, Fick's law was solved using spherical coordinates.

$\frac{d c}{d t}=D \frac{\partial^{2} c}{\partial r^{2}}+2 \frac{D}{r} \frac{\partial c}{\partial r}$

The boundary and initial conditions are,

$D \frac{d c}{d r}=\frac{i_{a p p}}{a_{V} L F}$ for $r=r_{0}$
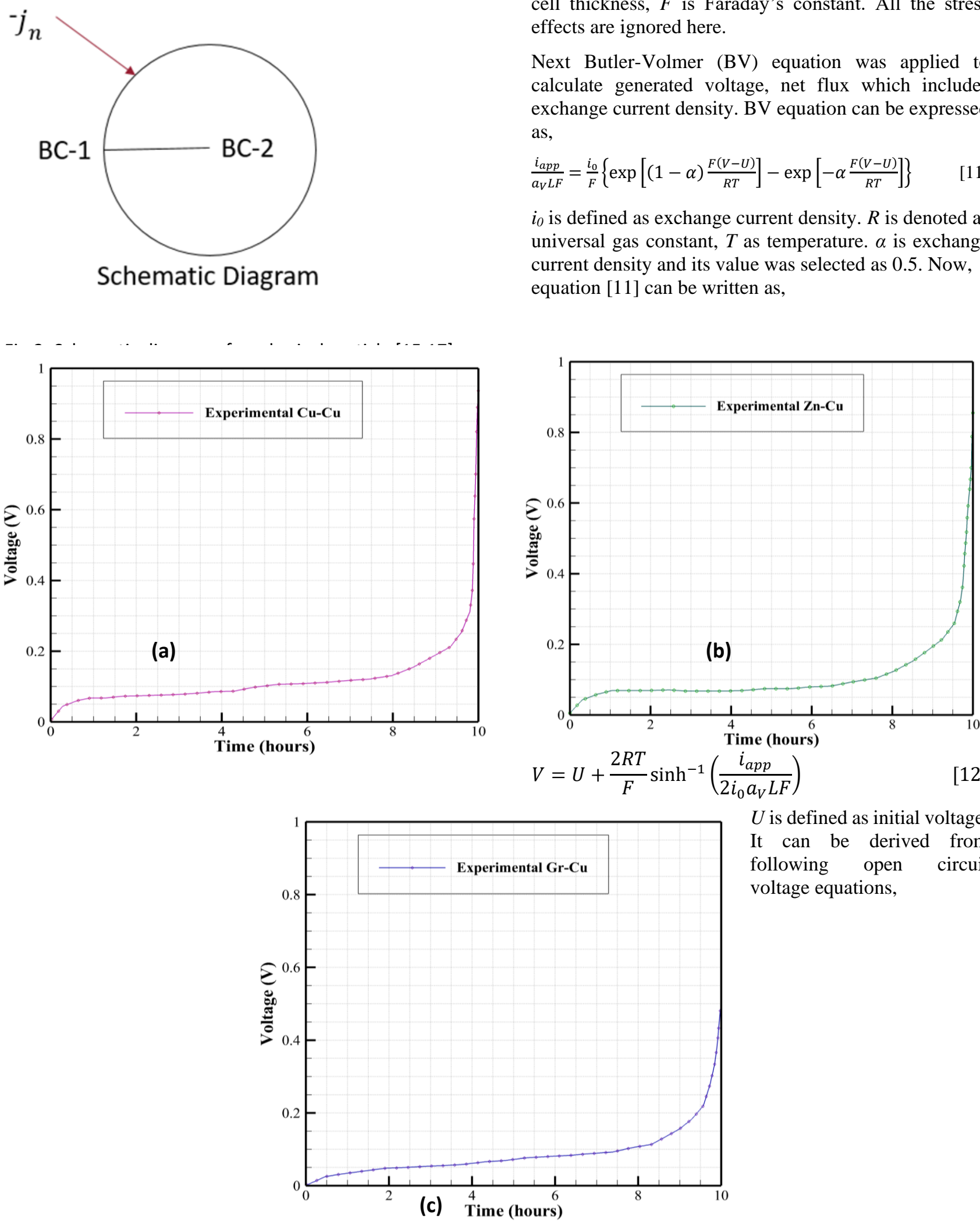

$U$ is defined as initial voltage. It can be derived from following open circuit voltage equations,

Fig.3: Experimental Voltage [V] curve with respect to Time [h] for (a) Copper-Copper (b) Zinc-Copper (c) Graphite-Copper 


$$
U=U_{0}\left(\frac{c}{c_{\max }}\right)
$$

In the above-mentioned equations, all the parameters are considered as constants apart from variables.

Here, all the equations are applied to generated simulated voltage curves using finite-element package COMSOL Multiphysics 5.6. Standard condition such as $25^{\circ} \mathrm{C}$ and 1 atm pressure was applied in our mathematical model. The parameters were chosen considering standard condition in mind. The list of parameters is given in Table-3. Extremely fine coarse mesh setup was used in generating simulated results. The computation was performed on Intel core i7 CPU using 7 cores.

\section{RESULTS AND DISCUSSION}

In the experiment three different anodic-cathodic combinations of cell setups were selected. Those are (i) Copper (anode) \& Copper (cathode), (ii) Zinc (anode) \& Copper (cathode), (iii) Graphite (anode) \& Copper (cathode). After preparing the cells, the voltage and current in the setups were observed for 10 hours. Then, change of Voltage with respect to Time is shown in Fig. 3. It is found that Copper-Copper setup generates maximum of $0.9362[\mathrm{~V}]$ after 10 hours as shown in Fig. 3(a). Whereas, the other two combinations Zinc-Copper and Graphite-Copper produce maximum of 0.8548 [V] and $0.5027[\mathrm{~V}]$ respectively during same time-period as
These voltages were self-generated as no external voltage or power was supplied. It is to be noticed that the combination of Copper-Copper produces the maximum amount of voltage during the specified time.

The variation of voltage with time was simulated using single particle one-dimensional mathematical model. After 10 hours, amount of voltage production was checked. Then, the model curve was used to check the experimental results as shown in Fig. 3. For simulation result, mass balance equation, Butler-Volmer equation and some parameters were used (table).

It can be witnessed form the figure that after 10 hours, time-interval, among the experimental data, the coppercopper setup's voltage curve matches the most with the model generated voltage curve as shown in Fig. 4. Even though Voltage vs Time curves of Zinc-Copper and Graphite-Copper are also close to model generated curve, they generated less amount of voltage in comparison to copper-copper combination. So, it is clear from the experiment and simulation that Copper-Copper setup is the best suited for food waste solution and can be used as a potential energy storage device.

\section{CONCLUSION}

In this investigation, a dual chamber MFC with various electrodes and food waste solution was studied. Three small scale MFCs setup were made with different

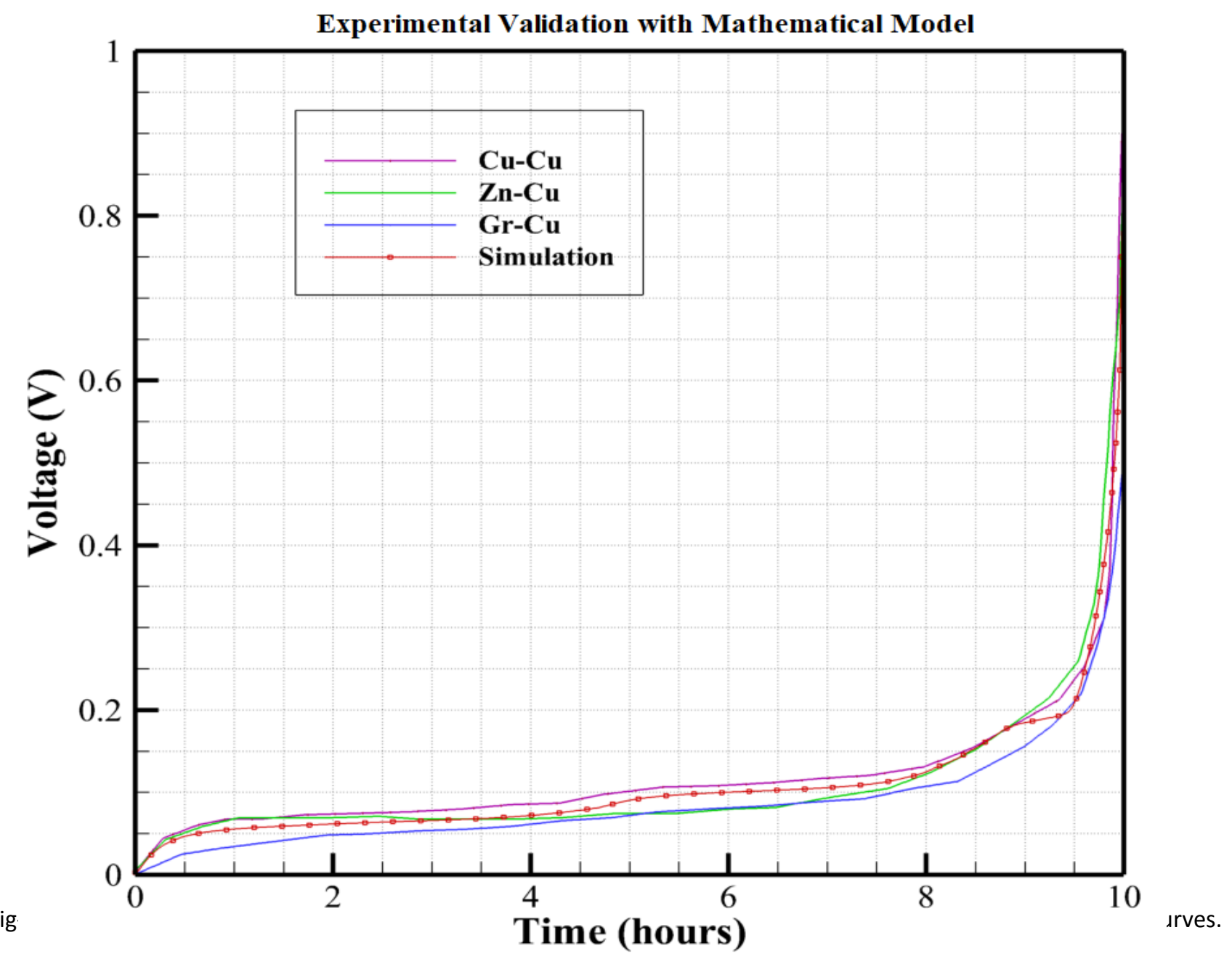

seen in Fig. 3(b) \& 3(c).

electrode combinations of Copper-Copper, Zinc-Copper 
and Graphite-Copper but same solution. After observing the cells, a variation of voltage with respect to time was plotted for each cell. It is seen that the voltage does not change much from 2 to 8 hours. It increases faster after 8 hours and the peak value was found after 10 hours which was nearly $900 \mathrm{mV}$. The generated power was approximately $90 \mu \mathrm{W}$ which is $19 \%$ more than of power generated from a double chamber MFC with dumped rubbish solution [18]. The value of peak voltage was only $15 \%$ less than the MFC, made with wastewater solution [12]. A one-dimensional single particle half-cell mathematical model was developed using these experimental results. Mass balance equation, ButlerVolmer equation and Fick's law for spherical particle was used to develop the model. Using the model in simulation, the experimental result was validated. From the validation it is found that out of three different combinations, Copper-Copper combination matches the best with simulation result. So, it has the best energy storage capacity.

From the study it can also be stated that food waste can be a good solution for microbial fuel cell as it has high number of organic compounds and also good biodegradability. Usage of food waste in MFCs can reduce the amount of its share in municipal waste and can be utilized to generate sustainable, clean and renewable energy. Further research on MFC with food waste can help improving quality and getting better results to be used practically.

\section{REFERENCES}

[1] H. Li, Y. Tian, J. Zhang, X. Pan, L. Li, S. Su, Electricity generation from food wastes and characteristics of organic matters in microbial fuel cell. Bioresource Technology 205 (2016) 104-110 doi:10.1016/j.biortech.2016.01.042

[2] K Bensaida, R Eljamal, Y Sughihara, O Eljamal ,The impact of iron bimetallic nanoparticles on bulk microbial growth in wastewater, Journal of Water Process Engineering, Vol 40.

doi: $10.1016 /$ j.jwpe.2020.101825

[3] G. Antonopoulou, I. Ntaikou, C. Pastore, L. di Bitonto, S. Bebelis, G. Lyberatos, An overall perspective for the energetic valorization of household food waste using microbial fuel cell technology of its extract, coupled with anaerobic digestion of the solid residue, Applied Energy $242 \quad$ (2019) 1064-1073. doi:10.1016/j.apenergy.2019.03.082

[4] C. Dumas, A. Mollica, D. Féron, R. Basseguy, L. Etcheverry, A. Bergel, Checking graphite and stainless anodes with an experimental model of marine microbial fuel cell. Bioresource Technology 99 (2008) 8887-8894. doi:10.1016/j.biortech.2008.04.054

[5] M. Rahimnejad, A. Adhami, S. Darvari, A. Zirepour, S. E. Oh. Microbial fuel cell as new technology for bioelectricity generation: A review. Alexandria Engineering Journal (2015) 54, 745-756.

doi: 10.1016/j.aej.2015.03.031

[6] N. Nik Azmi, N. Ghazali, A. Fikri, M. Ali, Studies on Power Generation and Wastewater Treatment Using Modified Single Chamber Microbial Fuel Cell, Advanced Materials Research. 1113 (2015) 823-827. doi:10.4028/www.scientific.net/amr.1113.823.

[7] E. Estrada-Arriaga, J. Hernández-Romano, L. GarcíaSánchez, R. Guillén Garcés, E. Bahena-Bahena, O. Guadarrama-Pérez et al., Domestic wastewater treatment and power generation in continuous flow air-cathode stacked microbial fuel cell: Effect of series and parallel configuration, Journal of Environmental Management. 214 (2018) 232-241.

doi:10.1016/j.jenvman.2018.03.007.

[8] Y. Zeng, Y. Fung Choo, B.-Hong Kim, P. Wu, Modelling and simulation of two-chamber microbial fuel cell. Journal of Power Sources 195 (2010) 79-89. doi:10.1016/j.jpowsour.2009.06.101

[9] Gude, V., 2016, "Wastewater treatment in microbial fuel cells - an overview", Journal of Cleaner Production, 122, pp. 287-307.

doi: 10.1016/j.jclepro.2016.02.022

[10] Logan, B., Hamelers, B., Rozendal, R., Schröder, U., Keller, J., Freguia, S., Aelterman, P., Verstraete, W., and Rabaey, K., 2006, "Microbial Fuel Cells: Methodology and Technology", Environmental Science \& Technology, pp. 40 (17), 5181-5192.

[11] Pinto, R., Srinivasan, B., Manuel, M., and Tartakovsky, B., 2010, "A two-population bioelectrochemical model of a microbial fuel cell", Bioresource Technology, 101(14), pp. 5256-5265.

doi: 10.1016/j.biortech.2010.01.122

[12] A. Hossain, N. Masud, M. Yasin and M. Ali, Proceedings of International Exchange and Innovation Conference on Engineering \& Sciences (IEICES), 6, 149-155 (2020).

[13] A. Hossain, Y. Cha, M. Song, S. Kim, Side Reaction Correction and Non-linear Exchange Current Density for Mathematical Modelling of Silicon Anode Based Lithium-Ion Batteries, (2020).

doi:10.13140/RG.2.2.36674.40646.

[14] C. Jin, H. Li, Y. Song, B. Lu, A. Soh, J. Zhang, On stress-induced voltage hysteresis in lithium ion batteries: Impacts of surface effects and interparticle compression, Science China Technological Sciences. 62 (2019) $1357-$ 1364.

doi:10.1007/s11431-018-9491-6.

[15] A. Hossain, S. Kim, Development of a physicsbased mathematical model to analyze the limitations of microparticle silicon-based lithium half cells IMECE Technical Presentation, (2020). doi: 10.13140/RG.2.2.30250.03526

[16] S. Pal, S. Damle, P. Kumta, S. Maiti, Modeling of lithium segregation induced delamination of a-Si thin 
film anode in Li-ion batteries, Computational Materials Science. 79 (2013) 877-887.

doi:10.1016/j.commatsci.2013.06.051

[17] A. Hossain, Development of a mathematical model to study the impact of state of charge dependent exchange current density on the generated voltage hysteresis of silicon anode-based lithium half cells, Journal of Mechanical Engineering Research. 12.1 (2021) 37-48. doi: 10.5897/JMER2021.0543

[18] Saha TC, Protity AT, Zohora FT, Shaha M, Ahmed I, et al., (2019) Microbial Fuel Cell (MFC) Application for Generation of Electricity from Dumping Rubbish and Identification of Potential Electrogenic Bacteria. Adv Ind Biotechnol 2: 010.

doi:10.24966/AIB-5665/100010 